\title{
American Jeremiads: The Winter of Our Discontent and Into The Woods
}

\section{Michael J. Meyer*}

John Steinbeck's fiction earned him the Nobel Prize in Literature, though more than that his writings reached a vast audience through filmed versions of his most read novels, including The Grapes of Wrath and East of Eden. Among Steinbeck's influences was Oswald Spengler, whose Decline of the West filters through Steinbeck and into other media, secondarily into the theatre. This piece examines one of Steinbeck's later novels, The Winter of Our Discontent in light of the influences of Spengler, and compares it with the Stephen Sondheim/James Lapine play, Into the Woods with the inference that Sondheim's play about the ills of materialism bears the traits of Steinbeck's influence. [Article copies available for a fee from The Transformative Studies Institute. E-mail address: journal@transformativestudies.org Website: http://www.transformativestudies.org (C2010 by The Transformative Studies Institute. All rights reserved.]

KEYWORDS: Steinbeck, Sondheim, Lapine, Materialism, Dysfunctional family, Spengler, The Decline of The West, Jeremiad.

Stephen Sondheim's career in musical theater began decades after John Steinbeck published his first novel. Nonetheless, a close examination of

\footnotetext{
${ }^{*}$ Michael J. Meyer, Professor Emeritus at DePaul University Chicago, is the Steinbeck bibliographer, a post he has held since the early 1990's. Widely published in collections of literary criticism on Steinbeck he has also edited three books himself including $A$ John Steinbeck Encyclopedia with Brian Railsback (Greenwood 2006), The Essential Criticism of Of Mice and Men (Scarecrow 2009) and The Grapes of Wrath: A Re-Consideration (Rodopi 2009). He is currently at work on volumes for the $50^{\text {th }}$ anniversary of Harper Lee's To Kill a Mockingbird and for the $60^{\text {th }}$ anniversary of Steinbeck East of Eden. He has also been named to edit Palgrave Macmillan volume on The Grapes of Wrath and $O f$ Mice and Men which will appear in 2012. Address corespondance to: Michael J. Meyer, DePaul University, 1712 N Normandy, Chicago Il 60707; e-mail: mjonmeyer@gmail.com.
} 